\title{
MODEL KONSEPTUAL PENERIMAAN SISTEM INFORMASI PERENCANAAN DAN PENGANGGARAN PERGURUAN TINGGI
}

\author{
Ni Kadek Dessy Hariyanti ${ }^{1)}$, I Putu Sutawinaya ${ }^{2)}$, dan I Ketut Suwintana ${ }^{\text {3) }}$ \\ ${ }^{1}$ Administrasi Niaga, Politeknik Negeri Bali \\ ${ }^{2}$ Teknik Elektro, Politeknik Negeri Bali \\ ${ }^{3}$ Akuntansi, Politeknik Negeri Bali \\ Email: dessyhariyanti@pnb.ac.id ${ }^{1)}$
}

\begin{abstract}
Abstrak - Sistem informasi perencanaan dan penganggaran (SIPERA) telah digunakan sejak tahun 2016 untuk pengajuan dan pemantauan kegiatan perencanaan dan penganggaran di Politeknik Negeri Bali. Salah satu kunci keberhasilan penerapan teknologi informasi dalam suatu organisasi adalah kemauan untuk menerima teknologi di antara para pengguna. Proses evaluasi perlu dilakukan untuk mengetahui keberhasilan dan penerimaan suatu teknologi. Oleh karena itu penting bagi manajemen untuk mengetahui bagaimana pengguna menerima dan mengadopsi SIPERA. Untuk menentukan model evaluasi yang tepat maka perlu dilakukan penelitian terkait dengan model konseptual evaluasi sistem informasi. Penelitian ini mengusulkan dan membentuk pemodelan konseptual untuk evaluasi keberhasilan dan penerimaan suatu sistem informasi. Model ini dibangun dengan modifikasi konsep model TAM. Modifikasi disesuaikan dengan karakteristik institusi sehingga dapat menggambarkan penerimaan serta adopsi teknologi sistem informasi SIPERA di PNB. Metodologi yang digunakan adalah tinjauan pustaka, gambaran umum modelmodel yang ada dan mengidentifikasi sistem untuk menghasilkan faktor-faktor yang mempengaruhi keberhasilan dan penerimaan suatu teknologi. Hasil penelitian terdapat 2 faktor utama dalam model konseptual yang diajukan yaitu factor keyakinan dan factor sikap pengguna. Faktor keyakiran pengguna berupa persepsi kebermanfaatan dan persepsi kemudahan penggunaan teknologi. Sedangkan faktor sikap berupa sikap terhadap penggunaan serta niat pelaku untuk menggunakan teknologi. Konseptual model penerimaan SIPERA yang dihasilkan dapat memberikan gambaran tentang indikator-indikator yang harus diperhatikan dan dapat dikembangkan untuk penelitian lebih lanjut.
\end{abstract}

Kata Kunci - Sistem Informasi Manajemen, Penerimaan Teknologi, model TAM

\section{PENDAHULUAN}

Salah satu kunci awal bagi keberhasilan implementasi teknologi informasi dan komunikasi dalam suatu organisasi adalah kemauan untuk menerima teknologi tersebut di kalangan pengguna. Penerimaan serta adopsi teknologi dapat dipengaruhi banyak hal di antaranya persepsi pengguna serta niat untuk menggunakan sistem.

SIPERA adalah Sistem Perencanaan dan Penganggaran di Politeknik Negeri Bali(PNB). Sistem ini telah digunakan sejak tahun 2016 untuk pengajuan dan monitoring perencanaan dan anggaran kegiatan di lingkungan PNB. Penggunanya adalah penglola subsatker dalam upaya mengajukan rencana kegiatan dan monitoring anggaran setiap tahunnya. SIPERA bertujuan untuk membantu operasional unit perencanaan untuk melakukan review rencana kegiatan subsatker, kemudian melakukan monitoring dan pengukuran kinerja terhadap pelaksanaan kegiatan tersebut. Tugas utama UP adalah untuk mengawal kegiatankegiatan satatuan unit kerja agar sesuai dan mendukung renstra institusi. Pada akhirnya SIPERA akan membantu dalam penyusunan Laporan Akuntabilitas Kinerja (LAKIP) tahunan Institusi
SIPERA yang telah diimplementasi sekitar 2 tahun mengalami banyak kendala, diantaranya persepsi pengguna yang beragam dan kebutuhan pengguna yang semakin berkembang. Untuk itu perlu kiranya dilakukan analisis tentang penerimaan sistem serta manfaatnya untuk kinerja subsatker di PNB. Untuk itu masalah penting yang diangkat adalah bagaimana model analisis evaluasi adopsi teknologi yang tepat bagi sistem perencanaan dan anggaran di lingkungan Politeknik Negeri Bali.

Evaluasi penerimaan dan adopsi teknologi SIPERA memerlukan motode implementasi tersendiri mengingat terdapat perbedaan karakteristik organisasi, proses bisnis, budaya organisasi dan karakteristik pengguna dalam institusi. Metode evaluasi ini akan memberikan gambaran tentang factor-faktor yang mempengaruhi kesuksesan adopsi teknologi SIPERA, sehingga dapat lebih efektif dan efisien diterima dan dimanfaatkan bagi penggunanya untuk meningkatkan kinerja institusi. Oleh karena itu dibutuhkan suatu model konseptual penerimaan sistem informasi Perencanaan dan pengganggaran di Politeknik Negeri Bali

Tujuan dari penelitian ini adalah untuk mendapatkan model penerimaan sistem SIPERA oleh subsatker di lingkungan Politeknk Negeri Bali. 
Terdapat 4 hal yang menjadi perhatian dalam analisis ini yaitu: Persepsi kegunaan (perceived usefulness), Persepsi kemudahan penggunaan (perceived ease of use), Sikap terhadap penggunaan (attitude toward usage), dan Niat perilaku untuk menggunakan (behavioral intention to use). Penelitian ini juga membentuk usulan hipotesis dan daftar pertanyaan kuisioner yang diharapkan dapat digunakan sebagai acuan dalam melakukan evaluasi penerimaan dan adopsi teknologi SIPERA yang akan diimplementasikan pada penelitian selanjutnya.

\section{METODE PENELITIAN}

Penelitian ini dilaksanakan di Politeknik Negeri Bali, dengan mengambil sample seluruh anggota sub satker di lingkungan institusi. Objek penelitiannya adalah Sistem Perencanaan dan Pengganggaran (SIPERA) Politeknik Negeri Bali. Penelitian ini menggunakan pendekatan deskriptif kualitatif, yaitu melakukan beberapa tahapan penelitian diantaranya: pertama, melakukan tinjauan umum terhadap penelitian sebelumnya yang telah meneliti tentang evaluasi kesuksesan penerimaan dan adopsi teknologi sistem informasi di suatu institusi. Kemudian dilanjutkan dengan tinjauan umum terhadap model konsep TAM yang ada untuk memberikan landasan teori terhadap usulan model konseptual yang akan dibangun. Dilanjutkan dengan membentuk kerangka model penerimaan sistem SIPERA dengan menentukan variable, indicator serta daftar pertanyaan yang menjadi intrumen model penelitian.

\subsection{Penelitian Terdahulu}

Penerapan teknologi baru dalam suatu organisasi akan berpengaruh pada keseluruhan organisasi, terutama pada sumber daya manusia [1]. Tujuan utama konsep TAM adalah menjadi dasar untuk memahami pengaruh faktor-faktor eksternal pada keyakinan internal (internal beliefs) dan tingkah laku (attitude). konsep TAM secara khusus digunakan dalam bidang sistem informasi untuk memprediksi penerimaan dan penggunaan dalam pekerjaan individual pemakai [2].

Budi [3] menggunakan konstruk asli konsep TAM yang dibuat oleh Davis [4] yaitu persepsi kegunaan (perceived usefulness) merupakan manfaat yang diharapkan oleh pengguna teknologi informasi dalam melaksanakan tugas, persepsi kemudahan penggunaan (perceived ease of use) sebagai suatu tingkatan dimana seseorang percaya bahwa penggunaan sistem tertentu dapat mengurangi usaha seseorang dalam mengerjakan sesuatu, sikap (attitude) dimana sikap suka atau tidak suka terhadap penggunaan suatu produk. Sikap suka atau tidak suka terhadap suatu produk ini dapat digunakan untuk memprediksi perilaku niat seseorang untuk menggunakan suatu produk atau tidak menggunakannya, minat perilaku (behavioral intention) dimana tingkat penggunaan sebuah teknologi komputer pada seseorang dapat diprediksi dari sikap perhatian pengguna terhadap teknologi tersebut, misalnya keinginan menambah pendukung, motivasi untuk tetap menggunakan, serta keinginan untuk memotivasi pengguna lainnya, penggunaan senyatanya (actual use) dimana seseorang akan puas menggunakan sistem jika mereka meyakini bahwa sistem tersebut mudah digunakan dan akan meningkatkan produktifitas mereka dan ditambahkan beberapa konstruk eksternal yaitu, pengalaman (experience), kerumitan (complexity). Keberhasilan dalam suatu sistem informasi bergantung pada bagaimana proses menjalankan sistem tersebut, kemudahan penggunaan sistem bagi pemakai, dan kemampuan pemakai sistem.

Shroff [5] menganalisis Model Penerimaan Teknologi (TAM) untuk menguji perilaku behavioural intention to use siswa dalam menggunakan sistem portofolio elektronik, yang berarti bagaimana siswa menggunakan sistem dan sesuai dengan kerangka kerja spesifik selama kursus berlangsung. Penelitian menggunakan kuesioner dimana 72 peserta menyelesaikan survei yang mengukur tanggapan mereka terhadap perceived usefulness (PU), perceived ease of use (PEOU), attitude towards usage (ATU) dan behavioural intention to use(BIU). Hasil penelitian menunjukkan bahwa kemudahan Penggunaan yang dirasakan siswa (PEOU) berpengaruh signifikan terhadap sikap terhadap penggunaan (ATU). Selanjutnya, perceived ease of use (PEOU) memiliki pengaruh signifikan yang paling kuat terhadap perceived usefulness (PU).

Sembada(2012) meneliti tentang penerimaan pengguna atas penggunaan CMS sistem informasi perpustakaan di Universitas Emil Salim dengan konsep TAM. Penelitian ini menggunakan 3 variabel bebas yaitu persepsi kegunaanm persepsi kemudahan dan factor sosial. Hasil menunjukkan bahwa penerimaan pengguna dipengaruhi oleh persepsi kegunaan, persepsi kemudahan dan factor sosial.

Yalina(2011) meneliti tentang Evaluasi Penerapan Sistem Informasi Perencanaan Pembangunan Daerah Pemerintah Provinsi Jawa Timur. Berdasarkan hasil penelitian ditemukan pembuktian bahwa semua faktor eksternal memiliki pengaruh positif terhadap tingkat penerimaan pengguna aplikasi SIPPD. Desain antarmuka dan mekanisme dukungan merupakan faktor eksternal yang sangat berpengaruh secara signifikan terhadap tingkat penerimaan pengguna 
pada aplikasi SIPPD Pemerintah Provinsi Jatim. Hasil penelitian ini juga menyatakan bahwa sikap terhadap penggunaan tidak signifikan terhadap tingkat penerimaan pengguna.

Fitriasyah,dkk[6] meneliti tentang analisis technology acceptance model (tam) terhadap faktor-faktor yang mempengaruhi penerimaan nasabah terhadap layanan internet banking (studi empiris terhadap nasabah bank di depok). Hasil penelitian ini menunjukkan bahwa personalisasi berpengaruh secara signifikan terhadap persepsi pengguna manfaat. Kemampuan menggunakan komputer berpengaruh secara signifikan terhadap persepsi pengguna manfaat dan kemudahan menggunakan sistem. Kepercayaan tidak berpengaruh secara signifikan terhadap persepsi pengguna manfaat, namum berpengaruh secara signifikan terhadap kemudahan menggunakan internet banking. Hasil pengujian statistik menunjukkan bahwa kemudahan menggunakan internet banking berpengaruh secara signifikan terhadap persepsi pengguna manfaat. Personalisasi, kemampuan menggunakan komputer, berpengaruh signifikan terhadap persepsi pengguna manfaat dan kepercayaan tidak berpengaruh secara signifikan terhadap persepsi pengguna manfaat. Selain itu kemampuan menggunakan komputer, berpengaruh secara signifikan terhadap kemudahan menggunakan internet banking dan kepercayaan tidak berpengaruh secara signifikan terhadap kemudahan menggunakan internet banking. Sedangkan personalisasi berpengaruh secara signifikan terhadap kemudahan menggunakan internet banking.

\subsection{Technology Acceptance Model}

Technology Acceptance Model (TAM) merupakan model yang paling luas dignakan untuk meneliti adopsi teknologi informasi dalam kurum waktu 18 tahun terakhir. konsep TAM merupakan model yang paling popular dan banyak digunakan dalam berbagai penelitain mengenai proses adopsi dari penggunaan atau penerimaan sistem informasi. Kesederhanaan dan kemampuan menjelaskan hubungan sebab akibat merupakan alasan utama penggunaan konsep TAM.

Technology Acceptance Model diperkenalkan pertama kali oleh Davis pada tahun 1989. konsep TAM dibuat khusus untuk pemodelan adopsi pengguna sistem informasi. Menurut Davis [4] tujuan utama TAM adalah ntuk mendirikan dasar penelusuran pengaruh factor eksternal terhadap kepercayaan, sikap (personalisasi) dan tujuan pengguna sistem. TAM mengganggap bahwa ada dua keyakinan variable perilaku utama dalam mengadopsi sistem informasi yaitu persepsi pengguna terhadap manfaat (perceived usefulness) dan persepsi pengguna terhadap penggunaan (perceived ease of use). Persepsi pengguna manfaat diartikan sebagai tingkat dimana seseorang percaya bahwa menggunakan sistem tertentu dapat meningkatkan kinerjanya, dan kemudahan menggunakan SIPERA diartikan sebagai tingkat dimana seseorang percaya bahwa menggunakan sistem dapat meningkatkan kinerjanya. Kemudahan menggunakan SIPERA juga berpengaruh pada persepsi pengguna manfaat yang dapat diartikan bahwa jika seseoarang merasa sistem tersebut mudah digunakan maka sistem tersebut berguna bagi mereka.

Secara teoritis dan praktis konsep TAM merupakan model yang dianggap pantas dalam menjelaskan bagaimana user menerima sebuah sistem. konsep TAM menyatakan bahwa behavioral intention to use ditentukan oleh dua keyakinan yaitu: pertama, persepsi kemanfaatan (perceived usefulness) yang didefinisikan sebagai sejauh mana seseorang yakin bahwa menggunakan sistem akan meningkatkan kinerjanya. Kedua, persepsi kemudahan (perceived ease of use) yang didefinisikan sebagai sejauh mana seseorang yakin bahwa penggunaan sistem adalah mudah. Berdasarkan hasil penelitian tersebut, kemudahan menggunakan dan persepsi pengguna manfaat merupakan persepsi yang sangat penting dalam memperkirakan proses adopsi teknologi informasi oleh individu maupun perusahaan. Davis[4] rnenyatakan bahwa kemudahan menggunakan mempengaruhi proses adopsi secara tidak langsung melalui persepsi pengguna manfaat karena persepsi pengguna manfaat lebih bersifat instrumental yang mengakibatkan teknologi baru lebih bermanfaat.

TAM merupakan salah satu jenis teori yang menggunakan pendekatan teori perilaku (behavioral theory) yang banyak digunakan untuk mengkaji proses adopsi teknologi informasi. Bagaimanapun yang namanya model yang bagus itu tidak hanya memprediksi, namun idealnya juga harus bisa menjelaskan. Rupanya dengan model TAM dan indikatornya memang sudah teruji dapat mengukur penerimaan teknologi. Dengan demikian menggunakan TAM maka akan mampu menjelaskan mengapa sistem informasi perpustakaan yang digunakan di perpustakaan bisa diterima atau tidak oleh pengguna.

TAM memberikan dasar untuk mengetahui pengaruh faktor eksternal terhadap kepercayaan, sikap, dan tujuan dari penggunanya.Disamping dibangun oleh dasar teori yang kuat, salah satu kelebihan dari model TAM lainnya adalah dapat menjawab kegalauan pertanyaan dari banyaknya sistem teknologi yang ternyata gagal diterapkan di perpustakaan. Hal ini disebabkan oleh penggunanya 
yang tidak mempunyai niat (intention) untuk menggunakannya. TAM menganggap terdapat 2 keyakinan individual, yaitu persepsi kemanfaatan (perceived usefulness, disingkat PU) dan persepsi kemudahan penggunaan (perceived easy of use, disingkat PEOU).

\section{HASIL DAN PEMBAHASAN}

\subsection{Model Konseptuan Penerimaan SIPERA}

Berdasarkan hasil abstraksi dan sintesis teori dari kajian pustaka, serta studi empirik terhadap hasil penelitian terdahulu, maka pada penelitian ini akan menganalisis adopsi teknologi SIPERA dengan menggunakan konsep TAM. Model konseptual penerimaan sistem SIPERA dapat digambarkan sebagai Gambar 1.

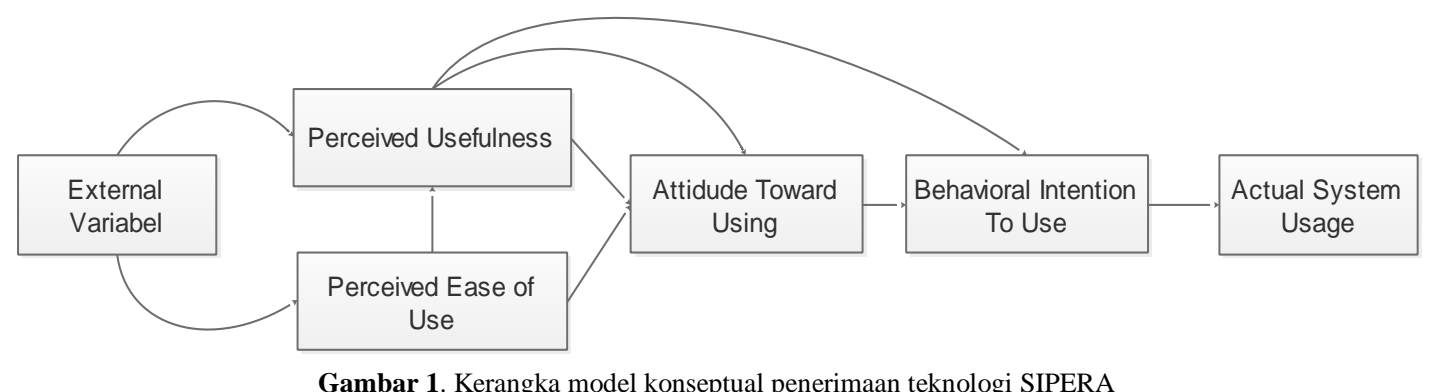

Dari kajian pustaka dan penelitian sebelumnya, maka sesuai kerangka konseptual penelitian di atas dapat ditentukan hipotesis penelitian yaitu:

H1 : Berdasarkan penelitian yang dilakukan Shroff[5], Perceived Ease of Use of the SIPERA (EOU) berpengaruh terhadap Perceived Usefulnes of the SIPERA (PU)

H2 : Berdasarkan penelitian yang dilakukan Shroff[5], Perceived Ease of Use of the SIPERA (EOU) berpengaruh terhadap Attitude Toward Using of the SIPERA(ATU)

H3 :Berdasarkan penelitian yang dilakukan Shroff[5], Perceived Usefulnes of the SIPERA (PU) berpengaruh terhadap Attitude Toward Using of the SIPERA(ATU)

H4 :Berdasarkan penelitian yang dilakukan Shroff [5], Perceived Usefulnes of the SIPERA (PU) berpengaruh terhadap Behavioral Intention to use the SIPERA(BI)

H5 :Berdasarkan penelitian yang dilakukan Shroff [5], Perceived Usefulnes of the SIPERA (PU) berpengaruh terhadap Actual System Usage of the SIPERA(ACU)

H6 :Berdasarkan penelitian yang dilakukan Shroff [5], Attitude Toward Using of the $\operatorname{SIPERA}(A T U)$ berpengaruh terhadap Behavioral Intention to use the SIPERA(BI)

H7 :Berdasarkan penelitian yang dilakukan Shroff [5], Behavioral Intention to use the $\operatorname{SIPERA}(B I)$ berpengaruh terhadap Actual System Usage of the SIPERA(ACU)

H8 :Berdasarkan penelitian yang dilakukan Shroff [5], Gender (GE) berpengaruh terhadap Perceived Ease of Use of the SIPERA (EOU)

H9 :Berdasarkan penelitian yang dilakukan Shroff [5], Gender (GE) berpengaruh terhadap Perceived Usefulnes of the SIPERA $(P U)$

H10 :Berdasarkan penelitian yang dilakukan Shroff [5], Age (AG) berpengaruh terhadap Perceived Ease of Use of the SIPERA (EOU)

H11 :Berdasarkan penelitian yang dilakukan Shroff [5], Age(AG) berpengaruh terhadap Perceived Usefulnes of the SIPERA (PU)

H12 :Berdasarkan penelitian yang dilakukan Shroff [5], Experience using Internet (EXI) berpengaruh terhadap Perceived Ease of Use of the SIPERA (EOU)

H13 : Berdasarkan penelitian yang dilakukan Shroff [5], Experience using Internet (EXI) berpengaruh terhadap Perceived Usefulnes of the SIPERA (PU)

\subsection{Variabel Model Konseptual}

Untuk menganalisis lebih jauh mengenai penerimaan SIPERA dengan model konsep TAM, maka beberapa variabel yang digunakan, antara lain:

\section{a. Persepsi kegunaan (perceived usefulness)}

Didefinisikan sebagai tingkat dimana pengguna percaya bahwa menggunakan SIPERA akan meningkatkan kinerja dan efektifitas dalam kegiatan administrasi usulan anggaran dan kegiatan pekerjaannya. Persepsi kegunaan ini juga dapat merupakan suatu kepercayaan (believe) tentang proses pengambilan keputusan. Dengan demikian jika seseorang merasa percaya bahwa sistem informasi berguna maka dia akan menggunakannya. Sebaliknya jika merasa percaya bahwa sistem informasi kurang berguna maka dia tidak akan menggunakannya. Variabel perceived usefullness (PU) memiliki 6 indikator 
(Sembada, 2012) yang menghasilkan 6 pernyataan yang akan disusun dalam kuisioner.

b. Persepsi Kemudahan (Perceived ease of use )

Didefinisikan sebagai sejauh mana seseorang percaya bahwa menggunakan teknologi akan bebas dari usaha. Dari definisinya diketahui bahwa ini juga merupakan suatu kepercayaan (believe) tentang proses pengambilan keputusan. Jika seseorang merasa percaya bahwa sistem informasi mudah digunakan maka dia akan menggunakannya, sebaliknya jika merasa percaya bahwa sistem informasi tidak mudah digunakan maka dia tidak akan menggunakannya. Variable Perceived ease of use memiliki memiliki 6 indikator (Sembada, 2012) yang menghasilkan 6 pernyataan yang akan disusun dalam kuisioner.

c. Sikap terhadap Penggunaan Teknologi (Attitude Toward Usage )

Menurut Davis et al. [5] attitude merupakan cermin perasaan suka atau tidak suka tentang kinerja dari target perilaku yang telah dilakukan. Variable Attitude Toward Usage memiliki 5 indikator (Shroff, 2011) yang menghasilkan 5 pernyataan yang akan disusun dalam kuisioner.

d. Minat Perilaku (Behavioral Intention )

Didefinisikan sebagai suatu keinginan (minat) seseorang untuk melakukan suatu perilaku yang tertentu. Seseorang akan melakukan suatu perilaku (behavior) jika mempunyai keinginan atau minat (behavioal intention) untuk melakukannya. Variabel behavioral intention yang memiliki 4 indikator (Yalina, 2011) yang menghasilkan 4 pernyataan yang akan disusun dalam kuisioner

e. Penggunaan sesungguhnya (Actual System Usage)

Didefinisikan sebagai suatu aktualitas penggunaan system informasi yang telah diimplementasikan. Seseorang akan melakukan suatu aktifitas menggunakan system karena pada kenyataannya sistem telah biasa digunakan pada pekerjan seharihari. Sseorang akan puas menggunakan sistem jika mereka meyakini bahwa sistem tersebut mudah digunakan dan akan meningkatkan produktifitas mereka Variabel Actual system usage memiliki 3 indikator yang menghasilkan 3 pertanyaan yang akan disusun dalam kuisioner

\subsection{Penyusunan Kuisioner}

Dari variabel-variabel model TAM diatas, maka disusun usulan kuisioner berdasarkan indikator-indikator yang didapatkan dari penelitian sebelumnya. Variabel Persepsi kegunaan (perceived usefulness) diwakili dengan (PU), Persepsi Kemudahan (Perceived ease of use ) diwakili dengan (EOU), Sikap terhadap Penggunaan Teknologi (Attitude Toward Usage ) Minat Perilaku (Behavioral Intention) seta Penggunaan Sesungguhnya (Actual System Usage). Komponen kuisioner dapat dilihat pada Tabel 1.

Tabel 1. Variabel, Indikator dan daftar pertanyaan kuisioner

\begin{tabular}{|c|c|c|c|}
\hline $\begin{array}{l}\text { Variabel Latens } \\
\text { Endogen }\end{array}$ & \multicolumn{2}{|r|}{ Indikator } & Pertanyaan Kuisioner \\
\hline \multirow{6}{*}{$\begin{array}{l}\text { Perceived } \\
\text { Usefulnes of the } \\
\text { SIPERA }(P U)\end{array}$} & PU1 & $\begin{array}{l}\text { Mendapatkan } \\
\text { yang dibutuhkan }\end{array}$ & $\begin{array}{l}\text { Saya mendapatkan informasi tentang } \\
\text { pengajuan usulan kegiatan dan } \\
\text { penganggaran institusi melalui SIPERA }\end{array}$ \\
\hline & PU2 & $\begin{array}{l}\text { mendapatkan } \\
\text { tambahan }\end{array}$ & $\begin{array}{l}\text { Saya mendapatkan informasi tambahan } \\
\text { yang cukup melalui SIPERA (misalnya: } \\
\text { format dokumen, informasi administrasi } \\
\text { Perencanaan anggaran, dll) }\end{array}$ \\
\hline & PU3 & $\begin{array}{l}\text { meningkatkan efektefitas } \\
\text { kerja }\end{array}$ & $\begin{array}{l}\text { Penggunaan SIPERA meningkatkan } \\
\text { efektifitas dalam } \\
\text { perencanaan kegiatan dan penganggaran } \\
\text { di Politeknik Negeri Bali }\end{array}$ \\
\hline & PU4 & memudahkan pekerjaan & $\begin{array}{l}\text { Saya sadar penggunaan SIPERA dapat } \\
\text { mempermudah } \\
\begin{array}{l}\text { administrasi } \\
\text { penganggaran }\end{array}\end{array}$ \\
\hline & PU5 & keuntungan penggunaan & $\begin{array}{l}\text { Saya sadar keuntungan menggunakan } \\
\text { SIPERA dalam kaitannya dengan } \\
\text { perencanaan kegiatan dan penganggaran } \\
\text { institusi }\end{array}$ \\
\hline & PU6 & kerugian penggunaan & $\begin{array}{l}\text { Saya sadar kerugian } \\
\text { menggunakan SIPERA }\end{array}$ \\
\hline
\end{tabular}


JUST TI, Volume 11 Nomor 1, Januari 2019: 1-7

\begin{tabular}{|c|c|c|c|}
\hline \multirow{6}{*}{$\begin{array}{l}\text { Perceived Ease } \\
\text { of Use of the } \\
\text { SIPERA (EOU) }\end{array}$} & \multirow{2}{*}{$\begin{array}{l}\text { EOU1 } \\
\text { EOU2 }\end{array}$} & $\begin{array}{lrr}\text { mudah diakses } & \text { dari } \\
\text { lingkungan } & \text { kampus }\end{array}$ & \multirow{2}{*}{$\begin{array}{l}\text { SIPERA dapat diakses dengan mudah di } \\
\text { lingkungan melalui } \\
\text { sion.pnb.ac.id } \\
\text { Karena telah berbasis WEB, maka } \\
\text { SIPERA dapat diakses dengan mudah di } \\
\text { luar lingkungan kampus }\end{array}$} \\
\hline & & $\begin{array}{l}\text { mudah diakses dari luar } \\
\text { kampus }\end{array}$ & \\
\hline & EOU3 & $\begin{array}{l}\text { mudah dipelajari cara } \\
\text { penggunaannya }\end{array}$ & $\begin{array}{l}\text { Penggunaan SIPERA dapat dengan } \\
\text { mudah dipelajari }\end{array}$ \\
\hline & EOU4 & $\begin{array}{l}\text { mudah dipahami alur } \\
\text { pengisian data nya }\end{array}$ & $\begin{array}{l}\text { Menu interface pada SIPERA dapat } \\
\text { dipahami dengan mudah }\end{array}$ \\
\hline & EOU5 & mudah digunakan & $\begin{array}{l}\text { Fasilitas dan Fitur yang disediakan } \\
\text { SIPERA mudah untuk digunakan }\end{array}$ \\
\hline & EOU6 & sistem yang fleksible & $\begin{array}{l}\text { Menurut saya, menu dalam SIPERA } \\
\text { berinteraksi secara fleksibel sehingga } \\
\text { memudahkan untuk menginput data }\end{array}$ \\
\hline \multirow{5}{*}{$\begin{array}{l}\text { Attitude Toward } \\
\text { Using of the } \\
\text { SIPERA }(\text { ATU })\end{array}$} & ATU1 & sifat awal pengguna & $\begin{array}{l}\text { Saya mempunyai keyakinan dan berfikir } \\
\text { secara positif mengenai penggunaan } \\
\text { SIPERA }\end{array}$ \\
\hline & ATU2 & kepercayaan pengguna & $\begin{array}{l}\text { Saya percaya dengan menggunakan } \\
\text { SIPERA merupakan ide yang baik }\end{array}$ \\
\hline & ATU3 & $\begin{array}{l}\text { implementasi penggunaan } \\
\text { sistem }\end{array}$ & $\begin{array}{l}\text { Implementasi dari penggunaan SIPERA } \\
\text { merupakan gagasan yang bijaksana dari } \\
\text { pimpinan Politeknik Negeri Bali }\end{array}$ \\
\hline & ATU4 & sistem yang menarik & $\begin{array}{l}\text { Menggunakan SIPERA merupakan } \\
\text { pengalaman yang menarik }\end{array}$ \\
\hline & ATU5 & $\begin{array}{l}\text { kenyamanan menggunakan } \\
\text { sistem keseluruhan }\end{array}$ & $\begin{array}{l}\text { Secara keseluruhan, saya nyaman } \\
\text { menggunakan SIPERA } \\
\text { pengajuan usulan kegiatan dalam } \\
\text { penganggaran }\end{array}$ \\
\hline \multirow{4}{*}{$\begin{array}{l}\text { Behavioral } \\
\text { Intention to use } \\
\text { the SIPERA }(B I)\end{array}$} & BI1 & $\begin{array}{l}\text { Pengguna } \\
\text { merekomendasikan sistem }\end{array}$ & $\begin{array}{l}\text { Saya merekomendasikan SIPERA pada } \\
\text { sesama Sub-satuan unit kerja di PNB }\end{array}$ \\
\hline & BI2 & sistem yang layak digunakan & $\begin{array}{l}\text { SIPERA layak digunakan untuk } \\
\text { administrasi perencanaan }\end{array}$ \\
\hline & BI2 & $\begin{array}{l}\text { kesadaran bahwa sistem } \\
\text { penting }\end{array}$ & $\begin{array}{l}\text { Alamat SIPERA saya simpan dalam } \\
\text { bookmark atau saya hafalkan }\end{array}$ \\
\hline & $\mathrm{BI} 3$ & $\begin{array}{l}\text { penggunaan sistem di masa } \\
\text { mendatang }\end{array}$ & $\begin{array}{l}\text { Saya setuju apabila dimasa mendatang } \\
\text { SIPERA tetap digunakan sebagai sistem } \\
\text { perencanaan anggaran dn kegiatan di } \\
\text { PNB }\end{array}$ \\
\hline \multirow{3}{*}{$\begin{array}{l}\text { Actual System } \\
\text { Usage of the } \\
\text { SIPERA }(A C U)\end{array}$} & ACU1 & menggunakan & $\begin{array}{l}\text { Setiap melakukan pengajuan usulan } \\
\text { kegiatan dan anggaran saya selalu } \\
\text { menggunakan SIPERA }\end{array}$ \\
\hline & ACU2 & $\begin{array}{l}\text { Mengkakses sistem sesuai } \\
\text { jadwal yang ditentukan }\end{array}$ & $\begin{array}{l}\text { Saya selalu mengakses SIPERA sesuai } \\
\text { jadwal untuk kelengkapan administrasi } \\
\text { usulan kegiatan }\end{array}$ \\
\hline & ACU3 & $\begin{array}{l}\text { Mengakses sistem dalam } \\
\text { jangka waktu tertentu }\end{array}$ & $\begin{array}{l}\text { Setiap melakukan akses ke } \\
\text { SIPERA saya memerlukan } \\
\text { sekurang-kurangnya } 20 \text { menit }\end{array}$ \\
\hline Gender & GE & Jenis Kelamin & Laki-laki dan Perempuan \\
\hline Ages & $\mathrm{AG}$ & Umur & $\begin{array}{l}<29 \text { tahun; 30-39 tahun; 40-50 tahun; > } \\
50 \text { tahun }\end{array}$ \\
\hline \multirow{3}{*}{$\begin{array}{l}\text { Experience } \\
\text { using the } \\
\text { SIPERA }\end{array}$} & EXE1 & $\begin{array}{ll}\begin{array}{l}\text { Mengikuti } \\
\text { sebelumnya }\end{array} & \text { Pelatihan } \\
\end{array}$ & $\begin{array}{l}\text { Saya telah mengikuti workshop } \\
\text { penggunaan SIPERA }\end{array}$ \\
\hline & EXE1 & $\begin{array}{l}\text { Pernah menggunakan sistem } \\
\text { yang sama sebelumnya }\end{array}$ & $\begin{array}{l}\text { Saya telah mengenal menu yang ada di } \\
\text { SIPERA karena hampir mirip dengan } \\
\text { sistem RKL }\end{array}$ \\
\hline & EXE1 & Fasih menggunakan internet & $\begin{array}{l}\text { Saya mudah menggunakan SIPERA } \\
\text { yang berbasis WEB, karena saya biasa } \\
\text { menggunakan internet sebelumnya }\end{array}$ \\
\hline
\end{tabular}

\section{KESIMPULAN}

Model konseptual penerimaan sistem SIPERA yang diusulkan merupakan modifikasi dari konsep model TAM, yang disesuaikan dengan karakteristik pengguna di lingkungan PNB. Variabel serta indikator yang mendukung analisis 
dipilih melalui kajian pustaka yang merujuk pada factor-faktor penting dalam kesuksesan penerimaan dan adopsi sistem SIPERA.

Hasil penelitian terdapat 2 faktor utama dalam model konseptual yang diajukan yaitu factor keyakinan dan factor sikap pengguna. Faktor keyakiran pengguna berupa persepsi kebermanfaatan dan persepsi kemudahan penggunaan teknologi. Sedangkan faktor sikap

\section{REFERENSI}

[1] Shinta Eka Kartika, 2009. Analisis Proses Penerimaan Sistem Informasi iCons Dengan Menggunakan Technology Acceptance Model pada Karyawan PT. Bank Negara Indonesia (Persero) Tbk. Di Kota Semarang. Tesis Universitas Diponegoro.

[2] Oladipupo Muhrtala Tijani, 2014. Built-In Functions and Features of Data Analysis Software: Predictors of Optimal Deployment for Continuous Audit Assurance. Scholars Journal of Economics, Business and Management. 1(1):h:7-18

[3] Budi Santoso, 2004. Pengaruh Percieved Usefulness, Perceived Ease of Use, dan Perceived Enjoyment Terhadap Penerimaan Teknologi Informasi (Studi Empiris di Kabupaten Sragen). Jurnal Studi Akuntansi Indonesia. 3(1): h: $1-15$

[4] Davis, Fred D. 1986. “Technology Acceptance Model for Empirically Testing New End-User Information System Theory and Results." Dissertation. Massachusetts Institute of Technology (MIT).

[5] Davis, Fred D., et. al., 1989. "User Acceptance of Computer Technology: A Comparison of Two Theoritical Models." Management Science, 35 (8), p.982-1002.

[6] Wijayanti, Ratih, Fitriansyah Hambali, dan Armaini Akhirson, 2011. Analisis Technology Acceptance Model (TAM) Terhadap FaktorFaktor yang Memengaruhi Penerimaan Nasabah Terhadap Layanan Internet Banking (Studi Empiris Terhadap Nasabah Bank di Depok). Dalam Proceeding PESAT (Psikologi, Ekonomi, Sastra, Arsitektur \& Sipil) Universitas Gunadarma, Vol. 4, h: 121-127.

[7] Aldino Gumilar Rahayu, 2013. Pengaruh Teknologi Informasi (Pendekatan Technology Acceptance Model) dan e-filling terhadap User satisfaction (Survey pada Wajib Pajak Badan di Wilayah KPP Madya Bandung). Skripsi Universitas Komputer Indonesia. berupa sikap terhadap penggunaan serta niat pelaku untuk menggunakan teknologi. Konseptual model penerimaan SIPERA yang dihasilkan dapat memberikan gambaran tentang indikator-indikator yang harus diperhatikan dan dapat dikembangkan untuk penelitian lebih lanjut.

[8] Arens, A.A., Elder, R.J., Beasley, M.S, 2012. Auditing and Assurance Service An Integrated Approach,14th Global Edition

[9] Adam, Desnis, Nelson Ryan, and Todd Peter, 1992. Perceived of Uselfulness, Ease of Use, and Usage of Information Technology: A Replication. Managemen Infromation System. Quartely Vil. 21/3.

[10] Jun Dai and He-li, 2013. Understanding Usage and Value of Audit Analytics for Internal Auditors: An Institutional Approach. Journal of Information \& Management. 2(1): h: 1-22

[11] Klopping, I.M. and E. McKinney. 2004. Extending the Technology Acceptance Model and TaskTechnology Fit Model to Consumer ECommerce. Information Technology, Learning, and Performance Journal. Vol. 22/1, Spring: 35-47.

[12] Leong, Y. L., 1997. ECPH Programme Hits Its Stride. Computer World. Vol. 13/3. Malhotra, $Y$ and D.F. Galletta. 1999. Extending the Technology Acceptance Model to Account for Social Influence: Theoritical Bases and Empirical Validation. Proceedings of the 32nd Hawaaii International Conference on System Sciences.

[13] Lihawa, Sri Mariati. 2012. Penerapan Technology Acceptance Model (Tam) Untuk Menganalisis Sikap Pengguna Terhadap Teknologi Sistem Informasi Akademik. Gorontalo : Universitas Negeri Gorontalo

[14] Lucyanda, Jurica, 2010. Pengujian Technology Acceptance Model (Tam) Dan Theory Planned Behavior (Tpb), JRAK, Vol. 2 Agustus 2010 Hal.1-14 1

[15] Mathieson, K. 1991. Precdicting User Intentions: Comparing The Thecnology Aceeptance Model with The Theory Planned Behavior. Information System Research. No. 2: 173222.

[16] Mukti Ayudewi, Handayaningsih, 2015. Analisis Penerimaan Pengguna Terhadap Sistem Informasi Manajemen Ruang Universitas Abc Menggunakan Teknologi Acceptance Model Sebagai Dasar Perbaikan Pada Sistem Fadlillah TECHSI : Jurnal Penelitian Teknik Informatika 